\title{
Decline in New Zealand's freshwater fish fauna: effect of land use
}

\author{
Michael K. Joy ${ }^{\mathrm{A}, \mathrm{E}}$, Kyleisha J. Foote ${ }^{\mathrm{B}}$, Pierce McNie ${ }^{\mathrm{C}}$ and Marina Piria ${ }^{\mathrm{D}}$ \\ A Institute for Governance and Policy Studies, Victoria University, Wellington, 6011, New \\ Zealand. \\ ${ }^{B}$ Institute for Agriculture and Environment, Massey University, Private Bag 11-222, Palmerston \\ North, 4442, New Zealand. \\ ${ }^{\mathrm{C}}$ Centre d'études de la forêt, Département des sciences biologiques, Université du Quebec á \\ Montréal, Montreal, QC, H3C 3P8, Canada. \\ DUniversity of Zagreb, Faculty of Agriculture, Department of Fisheries, Beekeeping, Game \\ Management and Special Zoology, Svetošimunska 25, HR-10000 Zagreb, Croatia. \\ ${ }^{\mathrm{E}}$ Corresponding author. Email: mike.joy@vuw.ac.nz
}

\begin{abstract}
The number of New Zealand's freshwater fish listed as threatened has increased since 1992 when the first New Zealand threat classification system list was compiled. In this study, temporal and land cover-related trends were analysed for data on freshwater fish distribution, comprising more than 20000 records for the 47 years from January 1970 to January 2017 from the New Zealand Freshwater Fish Database. The analysis included individual species abundance and distribution trends, as well as an index of fish community integrity, namely the Index of Biotic Integrity (IBI). Of the 25 fish species that met the requirements for analysis to determine changes in the proportion of sites they occupied over time, $76 \%$ had negative trends (indicating declining occurrence). Of the 20 native species analysed for the proportion of sites occupied over time, $75 \%$ had negative trends; $65 \%$ of these were significant declines and more species were in decline at pasture sites than natural cover sites. The average IBI score also declined over the time period and, when analysed separately, the major land cover types revealed that the IBI declined at pasture catchment sites but not at sites with natural vegetation catchments.
\end{abstract}

Additional keywords: biodiversity, biomonitoring, catchment area, introduced species.

Received 23 January 2018, accepted 30 July 2018, published online 10 September 2018

\section{Introduction}

Despite covering only $0.8 \%$ of the Earth's surface area, fresh waters contain one-third of all named vertebrate species and $9.5 \%$ of all known animal species (Strayer and Dudgeon 2010). Fresh waters support around $50 \%$ of the total fish species, but make up less than $0.3 \%$ of the global available surface water (Reid et al. 2013). Moreover, fresh waters are far more biodiverse than oceans, with one species per $15 \mathrm{~km}^{3}$ in fresh waters compared with one species per $100000 \mathrm{~km}^{3}$ named in the ocean biome (Ormerod et al. 2003).

Despite this rich diversity and the fact that new species were recently being described at an average of 305 per year (Reid et al. 2013), freshwater fish diversity is in decline worldwide (Dudgeon et al. 2006). Late in the 20th century it was estimated that more than $20 \%$ of the world's 10000 recorded freshwater fish species had become extinct, threatened or endangered (Moyle and Leidy 1992), and now freshwater fish are thought to be the most threatened group of vertebrates or chordates (Reid et al. 2013). By 2009, the International Union for Conservation of Nature (IUCN) Red List of Threatened Animals recorded over $40 \%$ of the $\sim 5000$ freshwater fish species they assessed globally as extinct or threatened with extinction (International Union for Conservation of Nature 2010).

Although these figures are alarming, they fail to fully account for the true extent of fish diversity declines. This likely underestimation is predictable for many reasons, including: (1) the meagre data available on fish biodiversity (e.g. there are over 10000 named freshwater fish species but only $\sim 5000$ have been assessed by the IUCN); (2) the inevitable lag time for data to become available for analysis, thus they fall behind actual range restrictions and extinctions when biodiversity is declining because of the time taken for updates to databases and for articles and reports to become available; and (3) there is a further lag caused by extinction debt, occurring where species, particularly the long-lived ones, survive initial environmental effects but the remaining populations are condemned to eventual extinction (Jackson and Sax 2010). Notwithstanding these limitations, where national data were available there is a clear and ominous declining trend for freshwater fish globally. For example, in South Africa, 63\% of freshwater fish were listed as 
threatened or endangered, whereas in Europe and Iran 42 and $22 \%$ were listed as threatened or endangered (Moyle and Leidy 1992). In the US, 37\% of freshwater fish species are threatened, with 17 species already extinct (Master et al. 1998). Projections are that $3.7 \%$ of freshwater species will become extinct in North America each decade; poignantly, this rate of decline is nearly fivefold higher than that of terrestrial animals (Ricciardi and Rasmussen 1999). More recent surveys show that $22 \%$ of the total assessed freshwater fish species in Africa are classified as threatened (Snoeks et al. 2011). In Europe, 39\% are threatened, with a further 4\% near threatened (Freyhof and Brooks 2011); in the Eastern Mediterranean region (consisting of catchments in Turkey, Syria, Lebanon, Israel and Jordan), $48 \%$ of the species assessed are considered threatened or near threatened (Freyhof et al. 2014).

Globally, the drivers of the declines and pressures on fresh waters are almost completely human induced (Strayer and Dudgeon 2010; Reid et al. 2013) and include eutrophication, habitat loss and population isolation through loss of access from the damming of rivers, flow alteration, habitat destruction, exotic species invasion, overharvesting and climate change (Allan and Flecker 1993). In the past decade, invasions by exotic species are widely considered to be one of the main threats to biodiversity and the second leading cause of animal extinctions (Clavero and Garcia-Berthou 2005; Millennium Ecosystem Assessment 2005), and may, in particular, be a threat to regions with a high proportion of endemism (Perdikaris et al. 2016; Piria et al. 2016, 2018). Ascertaining just how all these pressures on freshwater biodiversity interact is difficult, particularly the curly question of whether they are additive or multiplicative (Ormerod et al. 2010).

New Zealand has a freshwater fish fauna characterised by high levels of endemism that is under threat from several anthropogenic stressors, including habitat destruction or deterioration, commercial harvest, pollution and interactions with invasive alien species (Ling 2010). New Zealand's freshwater fish biodiversity has been declining for at least the past 100 years and includes one known extinction (the New Zealand grayling Prototroctes oxyrhynchus), which occurred early in the 20th century (McDowall 2010, 2011; Joy 2015). A recent assessment of New Zealand's freshwater flora and fauna concluded that New Zealand has 'one of the most endangered freshwater habitats in the world' (Freshwater Fish Specialist Group 2012). The increase in the number of species listed as at risk of extinction over the past 20 years gives some indication of the decline in fish occurrence, although the criteria for threat rankings have changed over time and these listings inescapably lag behind actual declines (Table 1). There have been three different threat classification systems introduced, in 1992, 2002 and 2007 (Table 1). The decline of freshwater biodiversity in New Zealand, revealed by the increasing number of species listed as threatened, matches or exceeds the declines noted in the rest of the world. This is not surprising given that the drivers of these declines of freshwater biodiversity in New Zealand are similar to those occurring globally, the only real difference being that they happened much more recently in New Zealand.

The aims of this analysis were to: (1) quantify the freshwater biodiversity declines suggested by the exceptionally high proportion of threatened or at-risk freshwater fish species in New Zealand and the increase in the number of threatened species over the past few decades; and (2) ascertain the key landscape-scale correlates of these changes. To achieve these aims, we analysed temporal trends in the occurrence and distribution of freshwater fish communities in New Zealand for the 47 years from 1970 to 2017 using data from an extensive database of fish distribution, the New Zealand Freshwater Fish Database (NZFFD; McDowall and Richardson 1983). For the second aim, to elucidate the associations between changes in occurrence over time, we analysed the relationships between land cover and fish distribution for the whole time period, as well as changes in those parameters over time at sites within different land cover and land use types.

\section{Materials and methods}

\section{Data sources}

The data on fish distribution were sourced from the NZFFD, which is maintained by New Zealand's National Institute of Water and Atmospheric Research (NIWA) and contains records of fish distribution from 1901 to the present. The data have been supplied by many different individuals and institutions and, by early 2017 , contained more than 30000 records. Each entry includes the site location details, the species of fish or large Crustacea found, the survey method used and, in some cases, more details, such as fish abundance and size data. The amount of detail for each record varies from only the presence or absence of individual species and no habitat details through to complete site descriptions and detailed abundance and fish size measures. Because of these differences and variability in survey methods used, abundance data recorded and measures of abundance, all data were converted to 'presence' or 'absence' to give a consistent level of accuracy for analyses.

Records of presence and absence for the 74 taxa recorded in flowing waters were extracted from the NZFFD for the time period January 1970-January 2017. The sites give a good spatial coverage of the two main islands of New Zealand, as well as Stewart and Chatham islands (Fig. 1). For this time period there were 20351 site records. However, annually, the number of sites surveyed and entered into the NZFFD over the 47-year period has not been consistent; surveyed sites have risen significantly over this time (Joy 2009) and peaked in 2005, when 1043 sites were surveyed. To account for this variation in annual sampling effort when analysing temporal trends, data for years were aggregated into sample units with an even number of sites equivalent to the most sampled year. Consequently, 2005 was used as the benchmark year for temporal trends and thus the 20351 sites were divided into 19 equal-sized groups of 1043 . The first time period contained more than 10 years from January 1970 to early 1980 , the next was less than 5 years from 1980 to 1984 , with the number of years in each group reducing until the 2000 decade, in which the time periods were close to yearly. To minimise the risk of finding false trends, only species that were present in all 19 time groups were retained for trend analysis. Twenty-five species passed the criterion and included five alien species (Table 2). This rule was also applied to smaller datasets when 
Table 1. Changes in threat status for native freshwater fish in New Zealand since threat classification began

References for numbers of species by year: 1992, Molloy and Davis (1992); 2002, Hitchmough (2002); 2005, Hitchmough et al. (2007); 2009, Allibone et al. (2010); 2013, Goodman et al. (2014). DOC, Department of Conservation; NZTCS, New Zealand Threat Classification System (Townsend et al. 2008)

\begin{tabular}{|c|c|c|c|c|c|c|}
\hline \multirow[t]{2}{*}{ Threat classification system } & \multirow[t]{2}{*}{ Category } & \multicolumn{5}{|c|}{ Number of species by year } \\
\hline & & 1992 & 2002 & 2005 & 2009 & 2013 \\
\hline \multirow{3}{*}{$\begin{array}{l}\text { DOC species priority setting system } \\
\text { (Molloy and Davis 1992) }\end{array}$} & Category A highest priority & 1 & & & & \\
\hline & Category B second priority & 4 & & & & \\
\hline & Category $\mathrm{C}$ third priority & 5 & & & & \\
\hline \multirow[t]{12}{*}{ Threat of extinction (Hitchmough 2002) } & Acutely threatened & & & & & \\
\hline & Nationally critical & & 1 & 1 & & \\
\hline & Nationally endangered & & 2 & 2 & & \\
\hline & Nationally vulnerable & & 1 & 3 & & \\
\hline & Chronically threatened & & & & & \\
\hline & Serious decline & & 2 & 1 & & \\
\hline & Gradual decline & & 10 & 13 & & \\
\hline & At risk & & & & & \\
\hline & Sparse & & 2 & 2 & & \\
\hline & Range restricted & & 2 & 4 & & \\
\hline & Data deficient & & 5 & 3 & & \\
\hline & Extinct & & 1 & 1 & & \\
\hline \multirow[t]{13}{*}{ NZTCS (Townsend et al. 2008) } & Threatened & & & & & \\
\hline & Nationally critical & & & & 4 & 5 \\
\hline & Nationally endangered & & & & 3 & 6 \\
\hline & Nationally vulnerable & & & & 7 & 10 \\
\hline & At risk & & & & & \\
\hline & Declining & & & & 13 & 14 \\
\hline & Relict & & & & 1 & 0 \\
\hline & Naturally uncommon & & & & 6 & 5 \\
\hline & Data deficient & & & & 0 & 1 \\
\hline & Extinct & & & & 1 & 1 \\
\hline & Non-resident native & & & & 3 & 3 \\
\hline & Not threatened & & & & 17 & 12 \\
\hline & Introduced and naturalised & & & & 20 & 20 \\
\hline Total native fish threatened or at risk & & 10 & 20 & 26 & 34 & 40 \\
\hline Percentage of native fish threatened or at risk & & 20 & & & 67 & 74 \\
\hline
\end{tabular}

individual land use classes were analysed separately, and this reduced the number of species to 19 for the land cover influence part of the analysis.

For each site record in the NZFFD, information on the site location identifies the specific river segment in a national digital river network, known as the River Environment Classification (REC; Snelder and Biggs 2002). This river network was derived from a $20-\mathrm{m}$ digital elevation model and comprises 560000 uniquely numbered reaches covering $426000 \mathrm{~km}$ of river networks in New Zealand. In the REC, each segment is associated with its unique upstream catchment and, among other parameters, each reach is classified into land use categories determined from satellite images to give the predominant catchment land use (Snelder and Biggs 2002). For this analysis, in relation to land cover-land use-related trends only, the major REC land cover classes (pasture, urban, indigenous forest, scrub, tussock and exotic forest) were used. To visualise temporal trends in different land cover classifications, the trend coefficients were plotted against each other for species at the two main REC classes: pasture and natural vegetation cover (together, these two land cover categories made up $73 \%$ of the sites, pasture $44 \%$ and natural vegetation cover $29 \%$ ).

\section{Fish Index of Biotic Integrity}

To assess overall changes in fish communities over time and in relation to land cover, a fish Index of Biotic Integrity (IBI; Joy and Death 2004) was calculated for all the site records from the NZFFD using the 19 time periods used for the individual species. This fish IBI was developed specifically for New Zealand to take into account the fact that the natural distribution of the predominantly migratory fish fauna is driven by distance from the sea and elevation by changing expectations for species richness in six metrics with increasing distance from the coast and elevation. The six metrics that make up the fish IBI are based on species richness of different guilds that reflect the availability of natural habitats, longitudinal access and the presence of alien species. These metrics are all weighted by elevation and distance separately, giving 12 metrics in total. The IBI score can range from 0 for no fish present up to a maximum of 60 for sites that contain all the species expected for that elevation or distance from the coast. The scoring was based on the fish communities at the best sites nationally (for details, see Joy and Death 2004). 


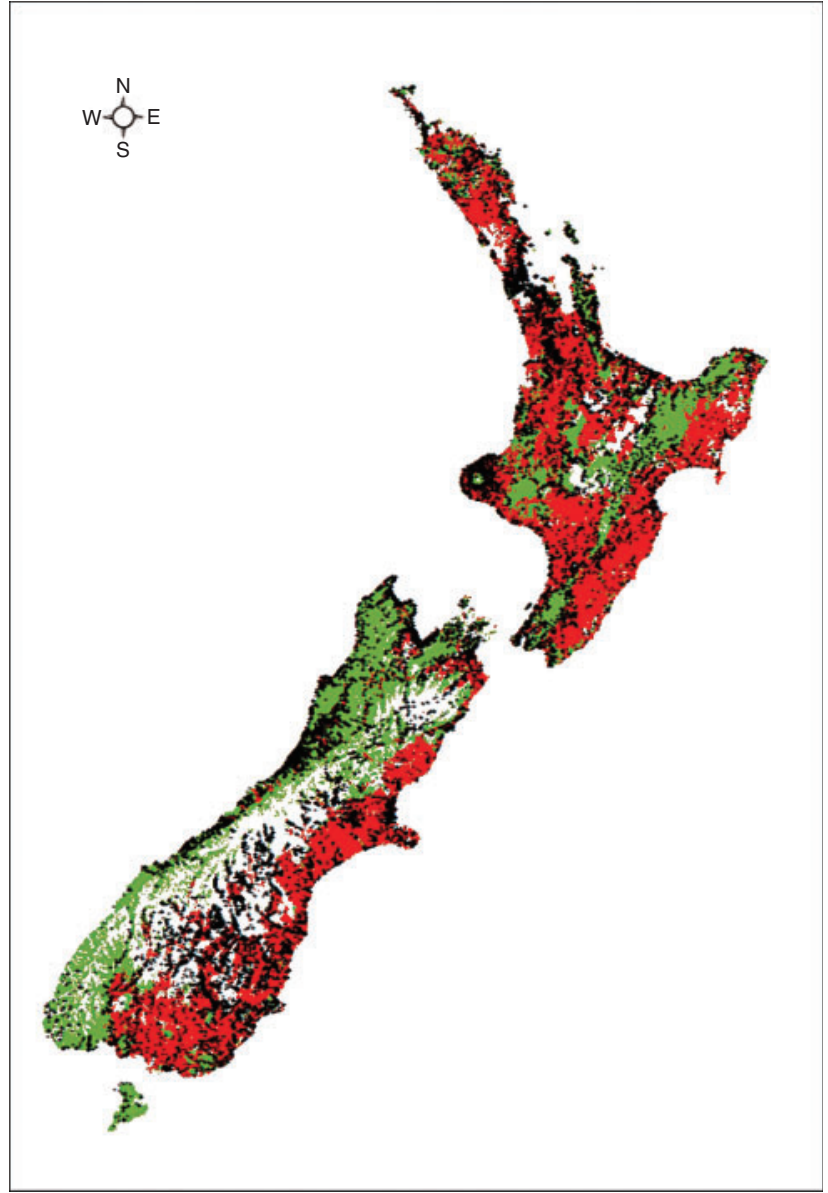

Fig. 1. Map of New Zealand showing the sample sites used in analyses from the New Zealand Freshwater Fish Database (McDowall and Richardson 1983) and the two main land cover classes: natural cover (indigenous forest and scrub combined; green) and pasture (red).

\section{Statistical analyses}

All analyses were conducted using R statistical software (ver. 3.4.2, R Foundation for Statistical Computing, Vienna, Austria, see http://www.R-project.org/). To test for temporal trends in the proportional occurrence of fish species, the non-parametric Mann-Kendall (Mann-K) trend test was used for each parameter investigated over the 19 time periods. The Mann-K test (Hirsch and Slack 1984) involves computing a statistic, $S$, which is the difference between the number of pairwise slopes that are positive minus the number that are negative. If $S$ is positive and has a significant $P$-value, then there is evidence of an increasing trend in the data. If $S$ is a negative value, then there is evidence of a decreasing trend in the data. To control for the possibility of increased probability of Type I error with each one of the multiple trend tests, the false discovery rate (Benjamini and Hochberg 1995) was used and reported as the adjusted $P$-value.

The parameters tested using the Mann-K trend test were: (1) the proportion of sites occupied by each of the 25 species in each of the 19 time periods of equal number of sites; (2) the mean IBI score for each of the time periods; and (3) trends in the proportion of sites occupied by each of the species in the two major land cover REC classes, pasture and natural cover (natural cover was the combination of the two REC classes indigenous forest and scrub). To visualise and assess the differences in trends at the two major land cover types, the Mann-K statistic scores from each land cover class were plotted against each other in a scatter plot for the 19 species meeting the requirement of being present in all time periods.

The relationships between land cover classes from the REC and fish communities were analysed by comparing the median IBI scores for each class using the non-parametric Kruskal-Wallis one-way analysis of variance (ANOVA; $\mathrm{R}$ package 'Kendall'). This test is the same as a one-way ANOVA, but the data are replaced by their ranks and the test is an extension of Mann-Whitney $U$-tests to three or more groups. A post hoc multicomparison pairwise test to see which, if any, of the groups were different was applied to the output from the Kruskal-Wallis test with pairwise comparisons using Dunn's test for multiple comparisons (Dunn 1964).

We recognise and acknowledge the potential for the confounding errors with the variability in species detectability, capture method and environmental relationships for the database records, but given the large number of records we are confident that the main trends analysed reflect actual changes and the environmental correlations with species occurrence. One potential issue when analysing a large database is if there is any sampling bias, where there is a change in the proportion of sites sampled from a particular land use over time. If, for example, there were more sites sampled in affected catchments over time, then this would tend to overemphasise declining occurrence. To asses this issue we analysed changes in the proportion of sites occupied by species in the time periods above for the two major land cover classes, namely natural vegetation cover ( $29 \%$ of sites) and pasture ( $44 \%$ of sites), over the 47 years. This analysis confirmed that, over the 47 years, increasingly more sites were surveyed in natural cover catchments than sites in pasture catchments; the slope for the difference in the number of sites per year in natural vegetation versus pasture was negative (indicating more sites were sampled in natural vegetation catchments over time; Mann-k $\tau=-0.384, P=0.0005)$. Thus, this increase in sites from undeveloped catchments would tend to understate declines (i.e. a tendency to make conclusions more conservative).

\section{Results}

Twenty-five fish species met the requirements for analysis for temporal changes in the proportion of sites they occupied over the 47 years to 2017 . In total, 19 (76\%) of these species had negative trends (indicating declining relative occurrence), and 13 of these $19(52 \%)$ were significant declines in proportional occurrence after correction for multiple comparisons (Table 2). Only one species, the alien Gambusia, showed a significant increase in proportional occurrence. Of the 25 species analysed, 20 were native species, 15 (75\%) of which had negative trends; of the native species, $13(65 \%)$ showed significant declines. Of the 13 species showing significant declines, all were classed as migratory, although for some of these species this strategy is facultative (Closs and Warburton 2016). Eight of the significantly declining species are endemic and one is alien (brown trout). All three known migratory strategies were represented in 
Table 2. List of species and their prevalence from the New Zealand Freshwater Fish Database (McDowall and Richardson 1983) found in flowing waters and in all time periods

Threat ranking and common name are from Goodman et al. (2014); migratory strategy is from McDowall (2010)

\begin{tabular}{|c|c|c|c|c|c|c|}
\hline Common name & Scientific name and authority & $\begin{array}{l}\text { Diadromous } \\
\text { strategy }\end{array}$ & Threat ranking & Prevalence $(\%)$ & Mann-Kendall $S$ & $\begin{array}{l}\text { Adjusted } \\
P \text {-value }\end{array}$ \\
\hline Lamprey & Geotria australis Gray, 1851 & Anadromous & Nationally vulnerable & 1.78 & -117 & 0.00 \\
\hline Longfin eel ${ }^{\mathrm{A}}$ & Anguilla dieffenbachii Gray, 1842 & Catadromous & Declining & 34.93 & -117 & 0.00 \\
\hline Common bully ${ }^{\mathrm{A}}$ & $\begin{array}{l}\text { Gobiomorphus cotidianus } \\
\text { McDowall, } 1975\end{array}$ & Amphidromous $^{B}$ & Not threatened & 15.73 & -113 & 0.00 \\
\hline Bluegill bully $^{\mathrm{A}}$ & Gobiomorphus hubbsi (Stokell, 1959) & Amphidromous & Declining & 3.08 & -108 & 0.00 \\
\hline Redfin bully ${ }^{A}$ & Gobiomorphus huttoni (Ogilby, 1894) & Amphidromous & Declining & 12.49 & -105 & 0.00 \\
\hline Shortjaw kokopu ${ }^{\mathrm{A}}$ & Galaxias postvectis Clarke, 1899 & Amphidromous $^{\mathrm{B}}$ & Nationally vulnerable & 2.09 & -74 & 0.04 \\
\hline Black flounder ${ }^{\mathrm{A}}$ & Rhombosolea retiaria Hutton, 1874 & Amphidromous & Not threatened & 0.80 & -71 & 0.01 \\
\hline Giant kokopu ${ }^{\mathrm{A}}$ & Galaxias argenteus (Gmelin, 1789) & Amphidromous ${ }^{\mathrm{B}}$ & Declining & 2.94 & -68 & 0.02 \\
\hline Torrentfish $^{\mathrm{A}}$ & Cheimarrichthys fosteri Haast, 1874 & Amphidromous & Declining & 6.90 & -67 & 0.02 \\
\hline Koaro & Galaxias brevipinnis Günther, 1866 & Amphidromous ${ }^{\mathrm{B}}$ & Declining & 8.73 & -32 & 0.20 \\
\hline Shortfin eel & Anguilla australis Richardson, 1841 & Catadromous & Not threatened & 18.17 & -25 & 0.40 \\
\hline Banded kokopu $^{\mathrm{A}}$ & Galaxias fasciatus Gray, 1842 & Amphidromous ${ }^{\mathrm{B}}$ & Not threatened & 10.92 & -45 & 0.12 \\
\hline Inanga & Galaxias maculatus (Jenyns, 1842) & Catadromous $^{\mathrm{B}}$ & Declining & 11.23 & -40 & 0.17 \\
\hline Dwarf galaxias $^{\mathrm{A}}$ & Galaxias divergens Stokell, 1959 & Non-migratory & Declining & 1.86 & -33 & 0.26 \\
\hline Cran's bully ${ }^{\mathrm{A}}$ & Gobiomorphus basalis (Gray, 1842) & Non-migratory & Not threatened & 3.87 & -16 & 0.60 \\
\hline Common smelt & Retropinna retropinna (Richardson, 1848 ) & Anadromous ${ }^{\mathrm{B}}$ & Not threatened & 4.55 & -2 & 0.90 \\
\hline Giant bully ${ }^{\mathrm{A}}$ & $\begin{array}{l}\text { Gobiomorphus gobioides } \\
\text { (Valenciennes, 1837) }\end{array}$ & Amphidromous & Not threatened & 1.66 & 5 & 0.80 \\
\hline Alpine galaxias ${ }^{\mathrm{A}}$ & Galaxias paucispondylus Stokell, 1938 & Non-migratory & Naturally uncommon & 2.16 & 48 & 0.10 \\
\hline Canterbury galaxias $^{\mathrm{A}}$ & Galaxias vulgaris Stokell, 1949 & Non-migratory & Declining & 4.39 & - & 0.62 \\
\hline Upland bully & Gobiomorphus breviceps (Stokell, 1939) & Non-migratory & Not threatened & 16.74 & 33 & 0.26 \\
\hline Goldfish $^{\mathrm{C}}$ & Carassius auratus (Linnaeus, 1758) & Non-migratory & Introduced & 2.28 & 37 & 0.20 \\
\hline Rainbow trout ${ }^{\mathrm{C}}$ & Oncorhynchus mykiss (Walbaum, 1792) & Anadromous ${ }^{\mathrm{B}}$ & Introduced & 6.24 & -41 & 0.16 \\
\hline Brown bullhead ${ }^{\mathrm{C}}$ & Ameiurus nebulosus (Lesueur, 1819) & Non-migratory & Introduced & 0.92 & -25 & 0.21 \\
\hline Gambusia $^{\mathrm{C}}$ & Gambusia affinis (Baird \& Girard, 1853) & Non-migratory & Introduced & 2.63 & 58 & 0.05 \\
\hline Brown trout ${ }^{\mathrm{C}}$ & Salmo trutta Linnaeus, 1758 & Anadromous ${ }^{\mathrm{B}}$ & Introduced & 23.64 & -95 & 0.00 \\
\hline
\end{tabular}

${ }^{\mathrm{A}}$ Endemic species.

${ }^{\mathrm{B}}$ Facultative diadromous.

${ }^{\mathrm{C}}$ Alien species.

the declining species list, eight were amphidromous (black flounder, torrentfish, common bully, bluegill bully, redfin bully, shortjaw kokopu, giant kokopu and koaro), two were anadromous (brown trout and lamprey) and two were catadromous (longfin and shortfin eels).

\section{Biotic integrity}

The species' temporal declines were mirrored in the analysis of temporal changes in the biological integrity of fish communities in New Zealand. The mean IBI score decreased over the 47 years from 20.4 in the 1970 s to 16.5 in the last time period (Mann-K $S_{1,18}=-73 ; Z=-0.427, P=0.01$ ); for pasture catchment sites the mean IBI score declined from 23.4 to 16.3 (Mann-K $\left.S_{1,18}=-77 ; Z=-0.45, P=0.007\right)$, whereas for native catchment sites the trend was not significant but the IBI increased from 19.7 to 24.6 (Mann-K $S_{1,18}=45 ; Z=0.263$, $P=0.12$; Fig. 2).

\section{Fish land cover-land use differences}

When IBI scores for each entry in the NZFFD were divided into the two major land cover classes from the REC, 19 species met the requirement of being in all time groups so were included in analyses. When the IBI scores for these two REC class were compared, marked differences were revealed (Kruskal-Wallis $\chi^{2}=852.78, P<0.000$; Table 3 ). A post hoc comparison following Dunn (1964) showed that the sites with catchments in natural cover (indigenous forest and scrub classes combined) had significantly higher scores than any of the other land cover types. Exotic forest and pasture sites were not significantly different from each other, but were significantly lower than the natural cover sites and higher than tussock and urban sites. Tussock sites had the lowest average IBI scores and urban sites had the next lowest scores.

\section{Fish land cover-land use temporal differences}

Temporal trends in IBI scores were analysed separately for the two major land cover classes from the REC: natural cover (indigenous forest and scrub combined), which contained 5813 records, and pasture farming catchments containing 8695 records. Together, these two groups accounted for $73 \%$ of the records. Trend analysis revealed that for the sites with pasture farming catchments, the IBI scores declined over the 47 years to 2017 (Mann-K $S=-77 ; \tau=-0.45, P=0.008$ ), whereas at 


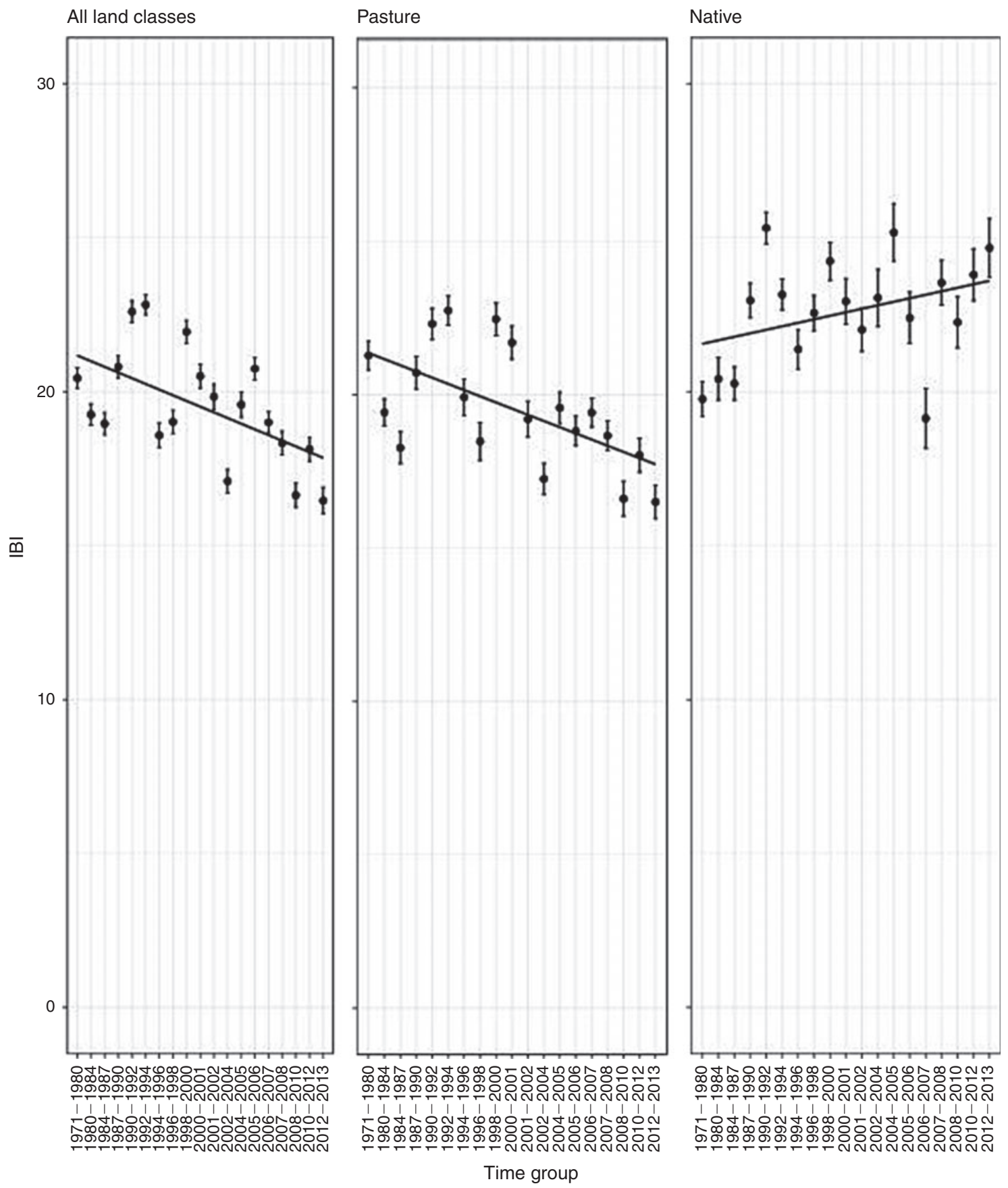

Fig. 2. Mean ( \pm s.e.m.) Index of Biotic Integrity scores for each time period for all land cover classes and pasture and natural vegetation sites separately.

indigenous forest sites there was no detectable temporal trend (Mann-K $S=45 ; \tau=0.263, P=0.12$ ).

When the proportion of sites occupied over the time period was analysed for each of the species within these individual land classes, clear patterns emerged for the 19 species included that met the requirement of being in all time groups at the two REC classes. At the pasture sites, $17(89 \%)$ species had negative trends, compared with $13(68 \%)$ species at the natural cover sites. All the significant trends after multiple comparison correction at the pasture sites were declines, whereas at the sites with catchments in natural cover all but one species (the shortfin eel) showed declining trends in occurrence (Table 4).

The plot of Mann-K scores for the two major land cover classes revealed the differences and similarity in trends for the different species in relation to land use (Fig. 3). The two land cover classes revealed strong differences in declines related to land use. Only introduced goldfish and Gambusia showed increases in occurrence at pasture sites (Fig. 3, lower right 
Table 3. Descriptive statistics for Index of Biotic Integrity scores for 19677 database entries over the 47 years for the six main River Environment Classification classes

\begin{tabular}{lcccccc}
\hline Statistic & Tussock & Bare & Urban & Pasture & Exotic forest & Natural forest \\
\hline Mean & 13.06 & 18.96 & 19.08 & 19.49 & 19.63 & 22.47 \\
s.e.m. & 0.26 & 0.5 & 0.4 & 0.12 & 0.36 & 0.16 \\
Median & 12 & 22 & 20 & 20 & 20 & 22 \\
Minimum & 0 & 0 & 0 & 0 & 0 & 0 \\
Maximum & 50 & 54 & 52 & 60 & 60 & 60 \\
Count & 2490 & 739 & 822 & 8612 & 1286 & 5728 \\
\hline
\end{tabular}

Table 4. Trend statistics for individual species in the main River Environment Classification (REC) classes that had significant trends after correction for multiple correlations

A negative Mann-Kendal $S$ score indicates declining proportional occurrence over the 47-year period

\begin{tabular}{llcc}
\hline REC class & Species & Mann-Kendal $S$ & Corrected $P$-value \\
\hline Pasture & Longfin eel & -0.131 & 0.00005 \\
& Black flounder & -0.85 & 0.0002 \\
& Common bully & -0.117 & 0.0005 \\
& Redfin bully & -0.95 & 0.001 \\
& Brown trout & -0.81 & 0.005 \\
& Lamprey & -0.79 & 0.03 \\
& Bluegill bully & -0.107 & 0.0002 \\
& Common bully & -0.73 & 0.01 \\
& Longfin eel & -0.67 & 0.02 \\
& Lamprey & -0.67 & 0.02 \\
& Brown trout & -0.74 & 0.03 \\
& Shortfin eel & 0.59 & 0.04 \\
\hline
\end{tabular}

quadrant). Eleven species showed declines at both land cover classes (Fig. 3, lower left quadrant). These species were the longfin eel, common bully, brown trout, bluegill bully, lamprey, redfin bully, shortjaw kokopu, giant kokopu, rainbow trout, torrentfish and inanga. Six species (shortfin eel, Crans bully, common smelt, banded kokopu, koaro and black flounder) showed declines at pasture sites and slight increases at natural cover sites (Fig. 3, upper left quadrant plot).

\section{Discussion}

Distinctive negative temporal and land cover-related trends in fish species occurrence were revealed for freshwater fish in New Zealand in this analysis. All native fish species had negative trends (indicating reducing occurrence), and there were clear differences in these trajectories in relation to land cover. The most severe diversity declines and lower fish community integrity scores (IBI) were associated with pasture catchments, and these findings reflect similar findings from other studies (Joy 2009; Ling 2010; McDowall 2010; Ramezani et al. 2016). Recent intensification of agriculture in New Zealand has been substantial, with a doubling of cow numbers in the past few decades, and this has had many negative effects on freshwater habitat, as well as freshwater quality and quantity (Julian et al. 2017).
Although land use intensity has been shown to be a strong driver of water quality (Julian et al. 2017), land use intensity data were not available for this analysis. Nonetheless, the negative effects of pasture catchments covering the full range of intensities on fish communities were revealed. Other studies have found that densities of both brown trout and native fish declined as the proportion of catchment in dairy farming increased (Ling 2010; McDowall 2011; Ramezani et al. 2016). In one recent study, Ramezani et al. (2016) found no trout in streams where dairy farms covered more than $50 \%$ of the catchment. The drivers of fish biodiversity declines in many studies have been found to be due to habitat effects, including increasing in-stream levels of dissolved nutrients, deposited fine sediment, increasing macrophyte cover and water temperature and decreasing water velocity with agricultural intensification (Harding 1999; Ramezani et al. 2016; Julian et al. 2017; Lee et al. 2017).

A recent comprehensive study on the relationship between land use intensity and water quality in New Zealand found that the greatest negative effect on river water quality in recent decades was high-producing pastures that require large amounts of fertiliser to support high densities of livestock (Julian et al. 2017). The same study found that the primary driver of the many trends of increasing nitrogen and phosphate levels in rivers was cattle density, with plantation forestry as the secondary predictor variable. Julian et al. (2017) further concluded that the legacy effect of these nutrients already lost to the environment but not seen yet in waterways and the continued agricultural intensification are expected to pose broad-scale environmental problems for decades. These impending declines in water quality do not bode well for an already declining freshwater fish fauna.

\section{Climate change}

Current predictions are that New Zealand will experience changes in mean annual temperature and precipitation, with drying in eastern regions and an increase in rain intensity in the west (Reisinger et al. 2010; Lundquist et al. 2011). These weather-related changes will very likely have significant negative effects on the freshwater fish fauna (Ling 2010), but that extra pressure combined with the recent expansion of New Zealand's dairy production has also placed greater pressure on water levels due to takes for irrigation in drier eastern regions of the South Island (Ling 2010; Julian et al. 2017). Thus, there are looming threats to freshwater biodiversity from climate change and intensification of agriculture.

\section{Dams}

Another effect on freshwater fish diversity likely behind many of the declines revealed in this study, but not included in this analysis (due to the unavailability of data), is the effect of the more than 2000 dams in New Zealand (Jellyman et al. 2013). Many studies have shown that fish community composition is altered above and below dams in New Zealand, with above-dam sites having lower species richness, a lower percentage of diadromous species and a higher percentage of alien species than below-dam sites (Joy and Death 2001; Jellyman and Harding 2012). The impoundments formed by dams mean more habitats for alien fish species, and now the majority of 


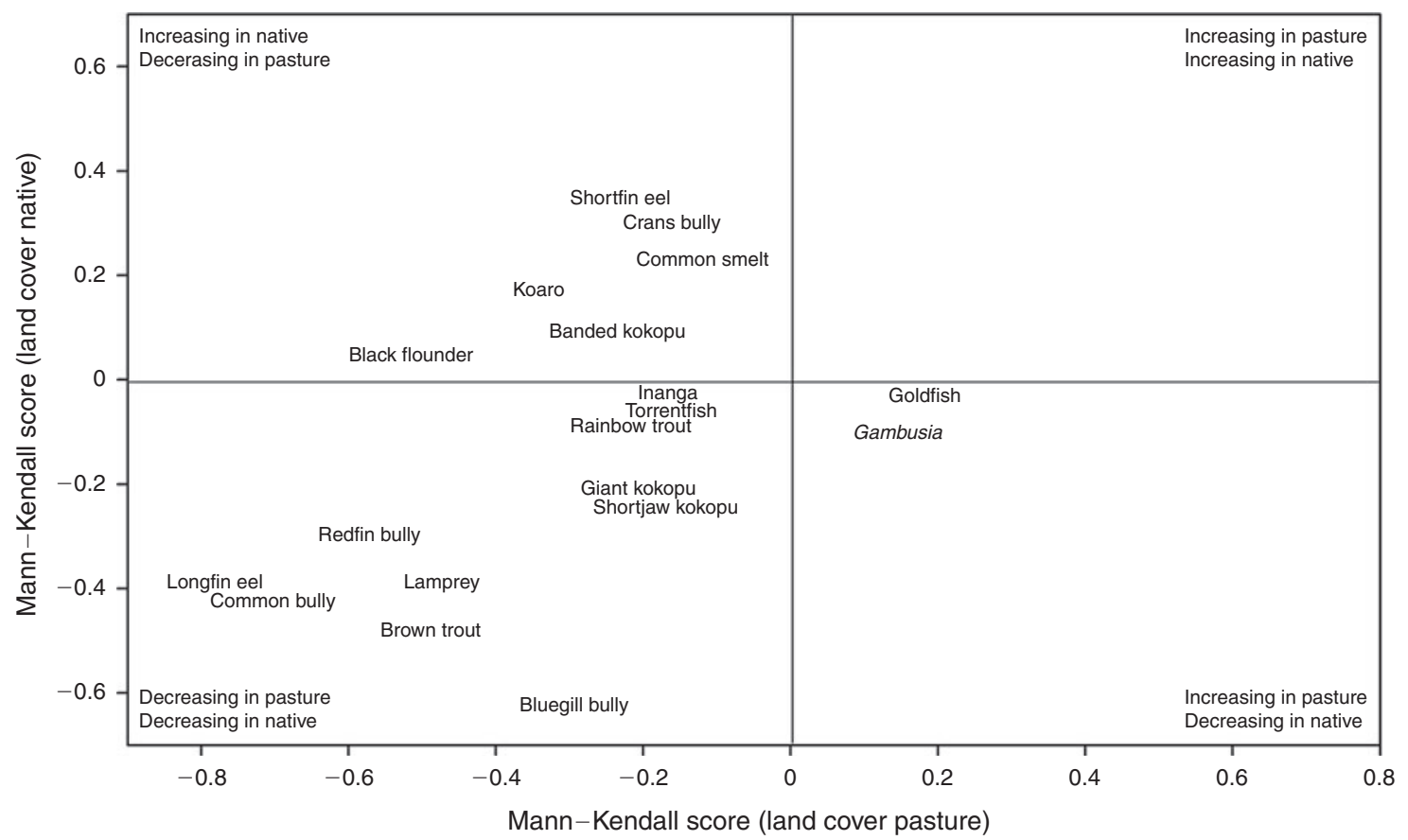

Fig. 3. Mann-Kendall scores for changes in the proportional occurrence of the 19 fish species that were present in all time periods over the 47 years from 1970 to 2017 plotted against each other for the two major land cover classes (pasture and natural vegetation).

impoundment lakes contain alien species. The dominance of alien species above dams is not limited to New Zealand, and this pattern has been repeatedly observed in studies around the world (e.g. Taylor et al. 2001; Han et al. 2008). Dams often facilitate the introduction, establishment and proliferation of alien fish species because the creation of artificial lakes can act as a 'stepping-stone' habitat for their continued spread (Johnson et al. 2008).

\section{Alien fish}

Another effect on freshwater biodiversity in New Zealand is the introduction of alien fish species. Many of these alien species are known to have negative effects on native fish communities through competition, predation and habitat modification (McIntosh et al. 1992, 2010; McDowall 2006). Furthermore, alien fish interactions have been revealed with land use influences (Crow et al. 2016). The New Zealand native fish fauna is unique in that it does not have planktivorous or herbivorous species. This, combined with habitat alteration and other effects described above, has allowed alien species, such as brown trout, koi carp and rudd, to effectively colonise, through range expansion or stocking, throughout most of New Zealand. Brown trout are aggressive predatory fish and have an adverse effect on ecosystem functioning (Townsend 2003) and on native Galaxiid species (Townsend and Crowl 1991; McDowall 2006), although they are an economically important fish species for New Zealand from a tourism perspective. Brown bullhead is one of the main invaders in open waters worldwide due their adaptability and tolerance to a wide range of environmental conditions (Piria et al. 2018); however, in New Zealand, a range of preventative measures was established and has minimised accidental spread (Rowe and Wilding 2012). Similar negative effects of alien fish to those found in New Zealand have been seen internationally with alien species and the resultant homogenisation of fish communities (Olden and Rooney 2006; Rahel and Olden 2008; Leprieur et al. 2009; Cucherousset and Olden 2011).

\section{Species increasing in occurrence and range}

The only significant positive change in occurrence found in this analysis was the introduced Gambusia, and their increase in occurrence was more pronounced in pasture catchments. This is consistent with a recent study that found the same positive association with pasture catchments and Gambusia presence and abundance (Lee et al. 2017). Lee et al. (2017) found that the percentage of the catchment in agricultural land use was associated with changes to physiochemical and habitat conditions, including increasing macrophyte cover and water temperature and decreasing water velocity. Gambusia is considered one of the 100 worst worldwide invasive species (Cote et al. 2010) and affects New Zealand's freshwater ecosystems by selective removal of invertebrate grazers (Ling 2004).

\section{Underestimation of true declines}

The results of this analysis very likely underestimate the true extent of the decline of New Zealand's freshwater fish fauna given the multiple inherent factors leading to the underestimation of changes in biodiversity. There are many such factors leading to the underrating of the true extent of the decline; six major factors are summarised below.

\section{Biological data imprecision}

The fact that only presence or absence data were used in this analysis, due to the lack of consistency in data collection in the 
NZFFD, inevitably tends to give conservative results because before species become absent at a site there is almost always a gradual decline in abundance (Manel et al. 2001). As a consequence, the end point of any abundance decline (a local extinction) is recorded as an absence in the database record, but the decline may have been occurring over decades. This is one disadvantage of having data collected by many different people for different purposes, an inevitable trade-off between data precision or quality and data quantity.

\section{Land cover-land use data imprecision}

The geographic information system (GIS)-based land cover classification used in this analysis (the REC) is inherently imprecise for two reasons: (1) it is a categorical classification based on a nominal threshold of continuous data; and (2) the classifications of areas into the pasture land cover category are based on the detection of pasture grasses from satellite images. However, this single category does not encompass the wide range of farming intensity found in New Zealand, from lowintensity sheep farming to high-input dairy. Thus, the clear relationship between faming intensity and effects on freshwater ecosystems in New Zealand (e.g. Ling 2010; Ramezani et al. 2016; Julian et al. 2017) is not incorporated fully in the analysis. Both these sources of imprecision lead to a lack of accuracy in the land use classification used to assess the relationship between land cover and fish trends.

\section{Unrecorded declines}

There is considerable anecdotal evidence of significant historic declines in fish abundance and distribution (e.g. McDowall 2011), but they are not available in the NZFFD so could not be included in this analysis.

\section{Extinction debt}

Extinction debt is where species, particularly long-lived ones, survive initial environmental effects but the remaining isolated populations are condemned to eventual extinction (Jackson and Sax 2010). In New Zealand there are many examples of longfin eels resident in headwater habitats above dams that they accessed many decades or even a century ago. Thus, although they show-up as a presence, they are, in effect, relict populations.

\section{Longevity lag}

Longevity lag is the presence in the fauna of long-lived fish, such as the longfin eel, that only breed once and at the end of their life. This means there can be a 100-year lag between when the last new individual is hatched and the last adult dies in the wild. Another problem occurs in long-lived species where a life span or generation time is greater than the period analysed in this study.

\section{Naturally rare species}

Several rare (mostly non-migratory) species had too few occurrence records in the database to be included in this analysis (i.e. they were not present in all the time periods analysed). These species are often very range restricted and are vulnerable to extinction.

\section{Conclusion}

This analysis confirmed the poor state of freshwater fish biodiversity in New Zealand. The temporal declines revealed in the proportional site occurrence for native fish species were worst in pasture catchments. This was similar to many other studies in New Zealand and internationally. The results presented here undoubtedly underrate the full extent of the declines for many fundamental reasons detailed above, as well as a temporal trend found in the data to sample proportionally more sites in natural vegetation catchments. Thus, this study highlighted the need for more consistent fish sampling using protocols now available to get more accurate and concise data on fish community changes by including abundance rather than just presence or absence. The drivers of the declines are similar to those found internationally, but the toll on New Zealand's freshwater fish community appears to be greater, with $74 \%$ of freshwater fish listed as threatened or at risk, considerably worse than the global average of $37 \%$ of freshwater species listed as extinct or threatened in 2010 (International Union for Conservation of Nature 2010). Although undoubtedly there are risks and trade-offs, it is clear that the continuing intensification of agriculture, along with the multiple effects of climate change, mean that without bold initiatives to reduce farming intensity and to restore habitats, New Zealand's mostly endemic freshwater fish fauna will be further imperilled.

\section{Conflicts of interest}

The authors declare that they have no conflicts of interest.

\section{Acknowledgements}

The authors thank all the contributors to the New Zealand Freshwater fish database and to NIWA for maintaining the database. Thanks also to the anonymous reviewers who greatly improved the manuscript. M. Piria was supported by a grant from the University of Zagreb, Faculty of Agriculture.

\section{References}

Allan, J. D., and Flecker, A. S. (1993). Biodiversity conservation in running waters. Bioscience 43, 32-43. doi:10.2307/1312104

Allibone, R., David, B., Hitchmough, R., Jellyman, D., Ling, N., Ravenscroft, P., and Waters, J. (2010). Conservation status of New Zealand freshwater fish, 2009. New Zealand Journal of Marine and Freshwater Research 44(4), 271-287. doi:10.1080/00288330.2010.514346

Benjamini, Y., and Hochberg, Y. (1995). Controlling the false discovery rate: a practical and powerful approach to multiple testing. Journal of the Royal Statistical Society - B. Methodological 57(1), 289-300.

Clavero, M., and Garcia-Berthou, E. (2005). Invasive species are a leading cause of animal extinctions. Trends in Ecology \& Evolution 20(3), 110. doi:10.1016/J.TREE.2005.01.003

Closs, G., and Warburton, M. (2016). Life histories of amphidromous fishes. In 'An Introduction to Fish Migration'. (Eds P. Morais and F. Daverat.) pp. 102-122. (CRC Press: Boca Raton, FL, USA.)

Cote, J., Fogarty, S., Weinersmith, K., Brodin, T., and Sih, A. (2010). Personality traits and dispersal tendency in the invasive mosquitofish (Gambusia affinis). Proceedings of the Royal Society - B. Biological Sciences 277(1687), 1571-1579. doi:10.1098/RSPB.2009.2128

Crow, S. K., Stewart-Koster, B., and Olden, J. D. (2016). Impacts of water allocation on native fish are mediated by an invasive predator and landscape context. In '11th International Symposium on Ecohydraulics', 7-12 February 2016, Melbourne, Australia. Available at http://proceedings. ise2016.org/tracks/1115/abstract/26080.html [Verified 29 August 2018]. 
Cucherousset, J., and Olden, J. D. (2011). Ecological impacts of nonnative freshwater fishes. Fisheries (Bethesda, Md.) 36(5), 215-230. doi:10.1080/03632415.2011.574578

Dudgeon, D., Arthington, A. H., Gessner, M. O., Kawabata, Z., Knowler, D. J., Lévêque, C., Naiman, R. J., Prieur-Richard, A. H., Soto, D. Stiassny, M. L. J., and Sullivan, C. A. (2006). Freshwater biodiversity: importance, threats, status and conservation challenges. Biological Reviews of the Cambridge Philosophical Society 81, 163-182. doi:10. 1017/S1464793105006950

Dunn, O. J. (1964). Multiple comparisons using rank sums. Technometrics 6(3), 241-252. doi:10.1080/00401706.1964.10490181

Freshwater Fish Specialist Group (2012). '2012 Annual Report.' (IUCN: Chester, UK.

Freyhof, J., and Brooks, E. G. E. (2011). 'European Red List of Freshwater Fishes.' (IUCN: Luxembourg.)

Freyhof, J., Ekmekçi, F. G., Atheer, A., Najim, R. K., Özuluğ, M., Hamidan, N., Küçük, F., and Smith, K. G. (2014). Chapter 3: freshwater fishes. In 'The Status and Distribution of Freshwater Biodiversity in the Eastern Mediterranean'. (Eds K. G. Smith, V. Barrios, W. R. T. Darwall, and C. Numa.) pp. 19-41. (IUCN: Gland, Switzerland.)

Goodman, J. M., Dunn, N. R., Ravenscroft, P. J., Allibone, R. M., Boubee, J. A. T., David, B. O., Griffiths, M., Ling, N., Hitchmough, R. A., and Rolfe, J. R. (2014). Conservation status of New Zealand freshwater fish, 2013. New Zealand Threat Classification Series 7. Department of Conservation, Wellington, New Zealand.

Han, M., Fukushima, M., Kameyama, S., Fukushima, T., and Matsushita, B. (2008). How do dams affect freshwater fish distributions in Japan? Statistical analysis of native and nonnative species with various life histories. Ecological Research 23(4), 735-743. doi:10.1007/S11284007-0432-6

Harding, J. S. (1999). Changes in agricultural intensity and river health along a river continuum gradient. Freshwater Biology 42, 345-357. doi:10. 1046/J.1365-2427.1999.444470.X

Hirsch, R. M., and Slack, J. R. (1984). A nonparametric trend test for seasonal data with serial dependence. Water Resources Research 20(6), 727-732. doi:10.1029/WR020I006P00727

Hitchmough, A. (2002). New Zealand Threat Classification System lists 2002. Threatened Species. Occasional publication 23. Department of Conservation, Wellington, New Zealand.

Hitchmough, R., Bull, L., and Cromarty, P. (2007). New Zealand Threat Classification System lists, 2005. Department of Conservation, Wellington, New Zealand.

International Union for Conservation of Nature (2010). 'The IUCN Red List of Threatened Species 2009 Update: Freshwater Fish Facts.' (IUCN: Cambridge, UK.)

Jackson, S. T., and Sax, D. F. (2010). Balancing biodiversity in a changing environment: extinction debt, immigration credit and species turnover Trends in Ecology \& Evolution 25(3), 153-160. doi:10.1016/J.TREE. 2009.10.001

Jellyman, P. G., and Harding, J. S. (2012). The role of dams in altering freshwater fish communities in New Zealand. New Zealand Journal of Marine and Freshwater Research 46(4), 475-489. doi:10.1080/ 00288330.2012 .708664

Jellyman, P. G., Booker, D. J., Crow, S. K., Bonnett, M. L., and Jellyman, D. J. (2013). Does one size fit all? An evaluation of length-weight relationships for New Zealand's freshwater fish species. New Zealand Journal of Marine and Freshwater Research 47(4), 450-468. doi:10. 1080/00288330.2013.781510

Johnson, P. T. J., Olden, J. D., and van der Zanden, M. J. (2008). Dam invaders: impoundments facilitate biological invasions into freshwaters. Frontiers in Ecology and the Environment 6(7), 357-363. doi:10.1890/ 070156

Joy, M. K. (2009). Temporal and land-cover trends in freshwater fish communities in New Zealand's rivers: an analysis of data from the
New Zealand Freshwater Database - 1970-2007. A report to the Ministry for the Ministry for the Environment, Massey University, Palmerston North, New Zealand.

Joy, M. K. (2015). Freshwaters in New Zealand. In 'Austral Ark; The State of Wildlife in Australia and New Zealand'. (Eds A. Stow, N. Maclean, and G. Holwell.) pp. 227-239. (Cambridge University Press: Cambridge, UK.)

Joy, M. K., and Death, R. G. (2001). Control of freshwater fish and crayfish community structure in Taranaki, New Zealand: dams, diadromy or habitat structure? Freshwater Biology 46(3), 417-429. doi:10.1046/J. 1365-2427.2001.00681.X

Joy, M. K., and Death, R. G. (2004). Application of the index of biotic integrity methodology to New Zealand freshwater fish communities Environmental Management 34(3), 415-428. doi:10.1007/S00267-0040083-0

Julian, J. P., de Beurs, K. M., Owsley, B., Davies-Colley, R. J., and Ausseil, A. G. E. (2017). River water quality changes in New Zealand over 26 years: response to land use intensity. Hydrology and Earth System Sciences 21(2), 1149-1171. doi:10.5194/HESS-21-1149-2017

Lee, F., Simon, K. S., and Perry, G. L. W. (2017). Increasing agricultural land use is associated with the spread of an invasive fish (Gambusia affinis). The Science of the Total Environment 586, 1113-1123. doi:10.1016/J.SCITOTENV.2017.02.101

Leprieur, F., Brosse, S., Garcia-Berthou, E., Oberdorff, T., Olden, J. D., and Townsend, C. R. (2009). Scientific uncertainty and the assessment of risks posed by non-native freshwater fishes. Fish and Fisheries 10(1) 88-97. doi:10.1111/J.1467-2979.2008.00314.X

Ling, N. (2004). Gambusia in New Zealand: really bad or just misunderstood? New Zealand Journal of Marine and Freshwater Research 38(3), 473-480. doi:10.1080/00288330.2004.9517254

Ling, N. (2010). Socio-economic drivers of freshwater fish declines in a changing climate: a New Zealand perspective. Journal of Fish Biology 77(8), 1983-1992. doi:10.1111/J.1095-8649.2010.02776.X

Lundquist, C., Ramsay, D., Bell, R. G., and Kerr, S. (2011). Predicted impacts of climate change on New Zealand's biodiversity. Pacific Conservation Biology 17(3), 179-191. doi:10.1071/PC110179

Manel, S., Williams, H. C., and Ormerod, S. J. (2001). Evaluating presenceabsence models in ecology: the need to account for prevalence. Journal of Applied Ecology 38, 921-931. doi:10.1046/J.1365-2664.2001.00647.X

Master, L. L., Flack, S. R., and Stein, B. A. (1998). 'Rivers of Life: Critical Watersheds for Protecting Freshwater Biodiversity.' (The Nature Conservancy: Arlington, VA, USA.)

McDowall, R. M. (2006). Crying wolf, crying foul, or crying shame: alien salmonids and a biodiversity crisis in the southern cool-temperate galaxioid fishes? Reviews in Fish Biology and Fisheries 16(3-4), 233-422. doi:10.1007/S11160-006-9017-7

McDowall, R. M. (2010). 'New Zealand Freshwater Fishes: a Historical and Ecological Biogeography.' (Springer: Dordrecht, Netherlands.)

McDowall, R. M. (2011). 'Ikawai: Freshwater fishes in Maori Culture and Economy.' (Canterbury University Press: Christchurch New Zealand.)

McDowall, R. M., and Richardson, J. (1983). The New Zealand freshwater fish database - a guide to input and output. Number 12, Ministry of Agriculture and Fisheries, Wellington, New Zealand.

McIntosh, A. R., Townsend, C. R., and Crowl, T. A. (1992). Competition for space between introduced brown trout (Salmo trutta) and a native Galaxiid (Galaxias vulgaris) in a New Zealand stream. Journal of Fish Biology 41, 63-81. doi:10.1111/J.1095-8649.1992.TB03170.X

McIntosh, A. R., McHugh, P. A., Dunn, N. R., Goodman, J. M., Howard, S W., Jellyman, P. G., O’Brien, L. K., Nystrom, P., and Woodford, D. J (2010). The impact of trout on galaxiid fishes in New Zealand. New Zealand Journal of Ecology 34(1), 195-206.

Millennium Ecosystem Assessment (2005). 'Ecosystems and Human Wellbeing: Biodiversity Synthesis.' (World Resources Institute: Washington DC, USA.) 
Molloy, J., and Davis, A. (1992). Setting priorities for the conservation of New Zealand's threatened plants and animals. Department of Conservation, Wellington, New Zealand.

Moyle, P. B., and Leidy, R. A. (1992). Loss of biodiversity in aquatic ecosystems: evidence from fish faunas. In 'Conservation Biology: The Theory and Practice of Nature Conservation Preservation and Management'. (Ed. P. L. Fiedler.) Vol. 1, pp. 127-169. (Springer US: New York, NY, USA.)

Olden, J. D., and Rooney, T. P. (2006). On defining and quantifying biotic homogenization. Global Ecology and Biogeography 15(2), 113-120. doi:10.1111/J.1466-822X.2006.00214.X

Ormerod, S. J., Marshall, E. J. P., Kerby, G., and Rushton, S. P. (2003). Meeting the ecological challenges of agricultural change: editors' introduction. Journal of Applied Ecology 40(6), 939-946. doi:10.1111/ J.1365-2664.2003.00872.X

Ormerod, S. J., Dobson, M., Hildrew, A. G., and Townsend, C. R. (2010). Multiple stressors in freshwater ecosystems. Freshwater Biology 55, 14. doi:10.1111/J.1365-2427.2009.02395.X

Perdikaris, C., Koutsikos, N., Vardakas, L., Kommatas, D., Simonovic, P., Paschos, I., Detsis, V., Vilizzi, L., and Copp, G. H. (2016). Risk screening of non-native, translocated and traded aquarium freshwater fishes in Greece using Fish Invasiveness Screening Kit. Fisheries Management and Ecology 23(1), 32-43. doi:10.1111/FME.12149

Piria, M., Povz, M., Vilizzi, L., Zanella, D., Simonovic, P., and Copp, G. H. (2016). Risk screening of non-native freshwater fishes in Croatia and Slovenia using the Fish Invasiveness Screening Kit. Fisheries Management and Ecology 23(1), 21-31. doi:10.1111/FME.12147

Piria, M., Simonović, P., Kalogianni, E., Vardakas, L., Koutsikos, N., Zanella, D., Ristovska, M., Apostolou, A., Adrović, A., Mrdak, D., Tarkan, A. S., Zanella, L., Milošević, D., Bakiu, R., Ekmekçi, F. G., Povž, M., Korro, K., Nikolic, V., Škrijelj, R., Kostov, V., Gregori, A., and Joy, M. K. (2018). Alien freshwater fish species in the Balkans vectors and pathways of introduction. Fish and Fisheries 19, 138-169. doi:10.1111/FAF.12242

Rahel, F. J., and Olden, J. D. (2008). Assessing the effects of climate change on aquatic invasive species. Conservation Biology 22(3), 521-533. doi:10.1111/J.1523-1739.2008.00950.X

Ramezani, J., Akbaripasand, A., Closs, G. P., and Matthaei, C. D. (2016). Instream water quality, invertebrate and fish community health across a gradient of dairy farming prevalence in a New Zealand river catchment. Limnologica 61, 14-28. doi:10.1016/J.LIMNO.2016.09.002

Reid, G. M., Contreras MacBeath, T., and Csatádi, K. (2013). Global challenges in freshwater-fish conservation related to public aquariums and the aquarium industry. International Zoo Yearbook 47, 6-45. doi:10. 1111/IZY.12020

Reisinger, A., Mullan, B., Manning, M., Wratt, D., and Nottage, R. (2010). Global and local climate change scenarios to support adaptation in New Zealand. In 'Climate Change Adaptation in New Zealand. Future Scenarios and Some Sectoral Perspectives'. (Eds R. Nottage, D. Wratt, J. F. Bornman, and K. Jones.) pp. 26-43. (Climate Change Centre, National Institute of Water and Atmospheric Research: Wellington, New Zealand.)

Ricciardi, A., and Rasmussen, J. B. (1999). Extinction rates of North American freshwater fauna. Conservation Biology 13(5), 1220-1222. doi:10.1046/J.1523-1739.1999.98380.X

Rowe, D. K., and Wilding, T. (2012). Risk assessment model for the introduction of non-native freshwater fish into New Zealand. Journal of Applied Ichthyology 28(4), 582-589. doi:10.1111/J.14390426.2012.01966.X

Snelder, T., and Biggs, B. J. F. (2002). Multi-scale river environment classification for water resources management. Journal of the American Water Resources Association 38(5), 1225-1239. doi:10.1111/J.17521688.2002.TB04344.X

Snoeks, J., Harrison, I. J., and Stiassny, M. L. J. (2011). The status and distribution of freshwater fishes. In 'The Diversity of Life in African Freshwaters: Under Water, Under Threat: An Analysis of the Status and Distribution of Freshwater Species throughout Mainland Africa'. (Eds W. R. T. Darwall, K. G. Smith, D. J. Allen, R. A. Holland, I. J. Harrison, and E. G. E. Brooks.) pp. 44-91. (IUCN: Cambridge, UK.)

Strayer, D. L., and Dudgeon, D. (2010). Freshwater biodiversity conservation: recent progress and future challenges. Journal of the North American Benthological Society 29(1), 344-358. doi:10.1899/08-171.1

Taylor, C. A., Knouft, J. H., and Hiland, T. M. (2001). Consequences of stream impoundment on fish communities in a small North American drainage. Regulated Rivers: Research and Management 17(6), 687-698. doi:10.1002/RRR.629

Townsend, C. R. (2003). Individual, population, community, and ecosystem consequences of a fish invader in New Zealand streams. Conservation Biology 17(1), 38-47. doi:10.1046/J.1523-1739.2003.02017.X

Townsend, C. R., and Crowl, T. A. (1991). Fragmented population structure in a native New Zealand fish: an effect of introduced brown trout. Oikos 61, 347-354. doi: $10.2307 / 3545242$

Townsend, A. J., de Lange, P. J., Duffy, C. A. J., Miskelly, C. M., Molloy, J., and Norton, D. A. (2008) New Zealand threat classification system manual. 978-0-478-14363-8, Department of Conservation, Wellington, New Zealand. 